\title{
The Despotic State ?-The Nature and Role of 18th Century Mughal Administration in the Great Divergence
}

\author{
Sagnik Bhattacharya ${ }^{1}$ \\ University of Groningen, the Netherlands
}

\begin{abstract}
Why Europe grew rich and 'Asia' became poor is the substance for the fiercely contested 'Great Divergence' debate where the prevailing Eurocentric view posits that European exceptionalism was responsible for the former's success. The essence of the picture painted in the arguments against 'oriental states' is a despotic and extractive one that hinders commercial activities. This paper tries to address this debate through looking at the nature and role of Mughal the administrative machinery and challenge image of despotic hegemony. In order to address the issue of commensurability of sources, the present author has only used European accounts and correspondences produced by the English East India Company and the Dutch VOC. The paper argues that the Eurocentric perspective essentially paints an ahistorical picture of the Mughal state by investigating European responses to the deaths of important Mughal emperors (Jahangir, Shah Jahan and Aurangzeb) and the economic consequences following it. Additionally, this paper also provides evidence of a strong role of bankers in the internal commercial system further undermining the image of the extractive state and supporting the 'Great Firm theory' of Karen Leonard. In conclusion, it is argued that the European-exceptionalism theory is fundamentally based on an orientalist imagination of South Asia and essentially suffers from the pitfalls of the 'historiography of decline' that plague the history of other 'Asian' empires such as the Qing and the Ottomans. Eighteenth century South Asia shows considerable similarities with early modern Europe and its commercial viability and agility does not appear to be dependent on the central government or the abilities of the emperor.
\end{abstract}

\section{Introduction-A Raging Debate}

Why India became the posterchild of oriental poverty and Europe emerged as the leading economic superpower in the nineteenth century is the substance matter for the fiercely fought Great Divergence debate within the field of global economic history. As Prasannan Parthasarathi elaborates, most arguments by Eurocentric historians and scholars since the $19^{\text {th }}$ century (e.g., Marx, Weber etc.) that have tried to explain this phenomenon, have essentially claimed that Europe was, in some ways exceptional, which set them on a path to economic prosperity while 'Asia,' (more specifically, the Ottoman Empire, China and India) were doomed to be a commercial failure due to their own political-economic arrangements and institutions such as caste, despotic, extractive states etc. ${ }^{2}$

\footnotetext{
'Correspondence: s.bhattacharya.1@student.rug.nl

${ }^{2}$ Prasannan Parthasarathi, Why Europe Grew Rich and Asia Did Not: Global Economic Divergence 1500 1800 (New York: Cambridge University Press, 2011).
} 
One very strong proponent of the idea of European exceptionalism is the BritishAustralian economist and historians Eric Jones, who in the very title of his book published in 1981, The European Miracle: Environments, Economies and Geopolitics in the History of Europe and Asia, makes his stance on the debate very clear. That he views European 'advancement' as a "miracle," and that he sees the decline of Asian economies as an intrinsic phenomenon is made clear in the course of his book. This essay, will essentially look at Jones' work as paradigmatic of a section of Eurocentric historiographic claims and try to reexamine the arguments in the light of archival material and also research from later eras with regard to the nature of and interaction with the late Mughal State and administrative apparatus in $18^{\text {th }}$ century India.

\section{'The Oriental Despot'}

Jones' picture pre-colonial 'Mughal India' is surprisingly aligned with the picture that Edward Said critiqued in his much acclaimed 1978 book. ${ }^{3}$ Jones' India is a place where traditional societal organisation is infallible and is a hindrance to 'modernisation.' The Mughal state is despotic and lives through the economic exploitation of the overwhelmingly agrarian population. The condition of the commerce is not conducive to economic advancement as there is very little opportunity for the accumulation of capital and an omnipresent threat of property appropriation by the ruling class resulting in an extremely high liquidity preference. In brief, Jones' India, is very similar to the picture painted by the author he quotes at the beginning of his chapter on that region-W. H. Moreland: "India of the seventeenth century must have been an inferno for the ordinary man." ${ }^{4}$

Jones takes this vision of India as his starting point and assumption and applies to it arguments similar to Douglas North's, that institutions-especially legal and property rights are crucial for economic growth and concludes that the reason for India's stagnation and decline was the absence of these fundamental components in their political economy.

Although his conclusion is theoretically sound, a closer examination reveals a number of problems with this assumption and sources. The reason why his image of India is such a good candidate for criticism on grounds of orientalist thought is because Jones uncritically uses sources such as travelogues and memoirs from the sixteenth and seventeenth centuries for example those by Jean-Baptiste Tavernier (1605 - 1689) and Francois Bernier (1620 1688). Sanjay Subrahmanyam has worked extensively to demonstrate why these documents

\footnotetext{
${ }^{3}$ Edward Said, Orientalism (New York: Vintage Books, 1978), $201-225$.

${ }^{4}$ Eric Jones, The European Miracle: Environments, Economies and Geopolitics in the History of Europe and Asia (Cambridge: Cambridge University Press, 2003), 192-201.
} 
are not only unreliable but invalid sources for historical research into Mughal Indian society due to problems of incommensurability, cultural translation and (in the case of Sir Thomas Roe's accounts) political expedience 5 .

If the Mughal State was that averse to commercial activities, then it does not account for the mushrooming of European trading centres all across the Indian coastline with imperial sanction (firman). Moreover, Jones gauges the liquidity preference of rich Indians from Bernier's statement that "owners of property declined $[\ldots]$ to repair their houses for fear of confiscation," "6 which clearly appears to be a hyperbole.

\section{The Problem}

Prasannan Parthasarathi and Eric Jones paint very different pictures of India and the Mughal Empire that appear to be at odds with each other. On the one hand, the Mughal empire is said to be the harbinger of a Pax Mughalica which allowed safe passage of goods and easy conduct of business at an unprecedented subcontinental scale, and on the other hand, the Mughal empire is seen as a large, despotic and extractive state ${ }^{7}$ that hindered a healthy inter-state competition in mercantile activity which is seen as the key to Europe's industrial success.

Christopher Bayly and Tirthankar Roy's work however, suggests an amalgamated version of the picture where they represent the Mughal administration as less than concrete and more of a tactful suzerainty over existing regional power bases ${ }^{8}$. In that case, it is logical to suggest that Mughal power not being uniform across the empire, the state provided enough avenues for regional commercial competition (as revenue collection was a regional matter) and also acted as a positive political entity guaranteeing safety and security of transport, legal protection, a reliable arbiter and a uniform commercial actor across Mughal territory.

The first part of this essay, in its quest to understand the nature of the Mughal administrative system will examine the role of the centralised Mughal state to function as an economically beneficial institution in the sense that Douglas North discussed in his seminal 1991 publication.

\footnotetext{
${ }^{5}$ Sanjay Subrahmanyam, Explorations in Connected History: Mughals and Franks (New Delhi: Oxford University Press, 2011), 152.

${ }^{6}$ Jones, The European Miracle, 196.

${ }^{7}$ For the clarification on the term 'extractive state', See: Daron Acemoglu and James A Robinson, Why Nations Fail: The Origins of Power, Prosperity and Poverty (New York: Crown, 2012).

${ }^{8}$ Parthasarathi, Why Europe Grew Rich and Asia Did Not, 54.
} 
Douglas North's work primarily outlined the necessity of institutions such as courts protecting against appropriation, security of the highways, political stability, secured means of transport etc. in order to lower what he called 'transaction costs' and promote trade. In the absence of these crucial institutions, firms and capital flows from regions of high transaction costs to regions of low transaction costs thereby maximising profitability for the enterprise. ${ }^{9}$

The method here, will be to look at the impact of the death of Emperor Aurangzeb (1707) widely regarded as a watershed moment in Mughal history-the economic impact of the decline of a strong central government and the ensuing war of succession, on the two regions of Surat and Bengal. Then, we will look at the main commercial institutions in Mughal India who were in regular contact with the Europeans, namely the shroffs (money changers), indigenous merchants etc. and the nature of their activities and their degree of independence. The aim here, is to investigate the effective degree of control that the centralised state (that Jones complains about) enjoyed and to answer the question: was the Mughal empire indeed an extractive, disorganised state with insecure commercial rights and disincentives to trading activities?

Sanjay Subrahmanyam has demonstrated the problem of commensurability of sources and the issues of cultural translation which make comparing the reactions and accounts in Asian and European sources a very difficult. ${ }^{10}$ In response, this paper only uses European sources from the records of the English East India Company and the Dutch VOC to explore the nature of their interactions with the State and consequently to infer the nature of the administrative machinery with regard to commerce.

\section{1. 'The Emperor is Dead'}

The death of the Mughal emperors was, in several cases followed by a struggle for the Peacock Throne among his living sons. Jones criticises the empire for a lack of systematic hereditary transitions and forward's Vincent Smith's claim that wars of succession were in fact the norm and created massive unrest all across the country jeopardising the economy and the disrupting the Pax Mughalica ${ }^{11}$. In order to examine the impact and importance of the

\footnotetext{
${ }^{9}$ Douglas North, Institutions, Institutional Change and Economic Performance (Cambridge: Cambridge University Press, 1990).

${ }^{10}$ Sanjay Subrahmanyam, Explorations in Connected History: Mughals and Franks (New Delhi: Oxford University Press, 2011), 154-155.

${ }^{11}$ Jones, The European Miracle, 197. And Vincent A. Smith, The Oxford History of India (Oxford: Clarendon Press, 1958), 433.
} 
centralised Mughal state which heavily relied on the capabilities of the emperor ${ }^{12}$, we shall examine the European accounts of the deaths of the two emperors Jahangir (1627) and Aurangzeb (1707) in the records of the English and Dutch East India Company(s) with particular focus on the disruption of trade and administration.

The deaths of both Emperors Jahangir and Aurangzeb were followed by a brief war of succession. In the case of Jahangir, the infamous 'Nur Jahan junta' was defeated after a series of bloody conflicts resulting in the death of Shehzada Shahryar, Nur Jahan's (Jahangir's second wife) house arrest and the enthronement of Prince Khurram or Shah Jahan (regnal title) as the Mughal emperor. ${ }^{13}$ In the case of Aurangzeb, his death was followed by a war of succession among his sons Muhammad Kam Baksh, Muhammad Azam Shah and Muhammad Mu'azzam who ascended the throne as Emperor Bahadur Shah but proved to be a very weak ruler.

With regard to the death of Jahangir in October 1627, the English East India Company accounts are surprisingly silent and only mention his death in the passing in a 27 page long report to the Company from Surat dated January 4, 1628:

"a suddaine rumour overspread the land with the King's death, which filled all men with feare and expectation, except only rebells and theeves that make itt their harvest. The newes was first whispered here the $19^{\text {th }}$ November, but within two dayes after, publikly divulged: whose decease was the first of the sayd moneth in his journey twixt Cashmere and Lahoare." 14

The rest of the letter mentions that there is ample speculation as to who would be succeeding the deceased Emperor but it also mentions that the Governor of Surat and the "principalls of these inhabitants (being naturall Persians) directed secretly their peticions unto Prince Charoom [Khurram]." ${ }^{15}$ Subsequent letters and reports also do not mention any large scale disruption of trade or money remittances to and from Surat. On February 17, 1628, the 'President and Council at Surat' is informed by factors at Agra that:

\footnotetext{
${ }^{12}$ Jones, The European Miracle, 197.

${ }^{13}$ S. Nurul Hasan, "The Theory of The Nur Jahan 'Junta'-A Critical Examination," Proceedings of the Indian History Congress 21 (1958): 324-35. http://www.jstor.org/stable/44145220.

${ }^{14}$ Report by President Kerridge, Richard Wylde, John Skibbow, Joseph Hopkins, William Martin and George Page at Surat to The Company, dated January 4, 1628. Published in: William Foster (ed.), The English Factories in India 1624 - 1629: A Calendar of Documents in the India Office Etc. (Oxford: Clarendon Press, 1909), 202.

${ }^{15}$ Same as above.
} 
"Shaw Jehaun sate in his royall throne the $4^{\text {th }}$ ditto and was saluted and proclaimed King, with the cuttbah read according to the custome of his ancestours [...] cruellie murthered all other princes of the blood." 16

These reports along with the absence of any extensive description of chaos are sufficient to conclude that although there was turmoil and confusion as a result of the Emperor's death, the chaos does not seem to be extensive and more importantly a hindrance to commercial activities as Jones suggested.

The precise nature of the turmoil one might anticipate as a result of the collapse or weakening of the administrative apparatus in the Mughal heartland is visible following the death of Emperor Aurangzeb in March 1707. Ashin Das Gupta discusses at length the coincidence of a marked increase in the number of European letters and reports mentioning 'banditry ${ }^{17}$ and the death of the last powerful emperor. In a letter from Surat to Amsterdam dated February 4, 1708 the Dutch Directeur at Surat writes:

"trade that had been hampered at the death of Aurangzeb, was now [as the war of succession developed] at a standstill throughout the country, because the routes round about Agra were too unsafe in the lower lands."

In another letter dated May 12, 1707 from Surat to Batavia, the Directeur reports that the shroffs who were responsible for remitting money to Agra had suspended business and the merchants trading in that part of the empire were in trouble ${ }^{19}$.

There is, in reality, three pieces of information that can be gathered from these two letters, firstly, that there was turmoil at the death of Aurangzeb, which means that longdistance trade was in fact protected and secured during the reign of the emperor, if one adds to this the information from a letter from Surat to Amsterdam dated March 19, 1710 that talks about customs problems at Cambay $^{20}$, one can easily construe the image of a fair and strong control of the Mughal Empire on the region of Surat before 1707 that not only guaranteed

\footnotetext{
${ }^{16}$ Report by Gregory Clement, John Bangham, Robert Clitherow, Ralph Cartwright and John Goodwin at Agra to the President and Council at Surat, dated February 17, 1628. Published in: Foster (ed.), The English Factories in India 1624 - 1629, 240.

${ }^{17}$ Ashin Das Gupta, 'Trade and Politics in Eighteenth Century India', in Muzaffar Alam and Sanjay

Subrahmanyam (ed.), The Mughal State 1526 - 1750 (New Delhi: Oxford University Press, 1998), 373.

${ }^{18}$ Letter from Surat to Amsterdam, Koloniaal Archief, Den Haag, 1629, p. 28. Quoted in: Sanjay Subrahmanyam and Muzaffar Alam, ed., The Mughal State 1526-1750 (New Delhi: Oxford University Press, 2013), 372.

${ }^{19}$ Letter from Surat to Batavia, Koloniaal Archief, Den Haag, 1638, p. 250. Quoted in: Sanjay Subrahmanyam and Muzaffar Alam, ed., The Mughal State 1526, 372.

${ }^{20}$ Letter from Surat to Batavia, Koloniaal Archief, Den Haag, 1660, p. 1953. Quoted in: Sanjay Subrahmanyam and Muzaffar Alam, ed., The Mughal State 1526, 372.
} 
protection from brigandage but also ensured maintenance of customs regulations that had been agreed between the traders and the Court. Furthermore, the letter to Batavia, concerns the services of the 'shroffs' or money-changers (bankers), that seem to have been functional during the reign of the emperor and was suspended at the death of the same.

Ashin Das Gupta concluded from the evidence available from the sources quoted above that "all available evidence indicates the fact that a serious breakdown affected the heartland of the empire [...] and security of transport disappeared." ${ }^{21}$ This insecurity is noted in the travelogues of Simon Diodati-a Dutch factor who left Agra on 26 December 1716 and reached Surat on 24 February 1717 having been attacked multiple times by "armed peasants" (gewapande boeren) and being forced to take a detour through trackless forests and going further south (where they came to know of a Maratha advance). ${ }^{22}$

Bernard Cohn also notes that the Mughals deployed market regulators who maintained accuracy of weights and currency in the markets, and discovered that they seem to have disappeared in Benaras around the 1710s. This is not only one example of Mughal administrative machinery but also of the decline of the same after $1707 .^{23}$

The result of all this was that the import of commodities from the interior died out and Surat gradually declined as a viable centre for trade. This decline in trade is noticeable as early as 1708 when the import of Dariabadi chadar (beadspreads from Lucknow) was stopped and in 1710 when the best quality of indigo grown in the vicinity of Agra (the Biana indigo) was no longer available ${ }^{24}$. The procurement that was still possible costed 50 percent more in transport and additionally, records show a 10-15 percent loss on remittances from Surat to $\operatorname{Agra}^{25}$ a classic case of increasing transaction costs.

Records from the English East India Company's factors in Bengal about the death of Emperor Aurangzeb though apprehensive, show much more limited impact on that region. On April $3^{\text {rd }}, 1707$ it is reported that "the whole town and factory are thrown into confusion

\footnotetext{
${ }^{21}$ Sanjay Subrahmanyam and Muzaffar Alam, ed., The Mughal State 1526-1750 (New Delhi: Oxford University Press, 2013), 372-373.

${ }^{22}$ Sanjay Subrahmanyam and Muzaffar Alam, ed., The Mughal State 1526, 372.

${ }^{23}$ Bernard S. Cohn, "Political Systems in Eighteenth Century India: The Benaras Region", Journal of the American Oriental Society vol. 82 no. 3(1962): 319.

${ }^{24}$ Letter from Surat to Amsterdam, Koloniaal Archief, Den Haag, 1645 p. 162 and 1689 p. 224-225. Quoted in: Sanjay Subrahmanyam and Muzaffar Alam, ed., The Mughal State 1526, 373.

${ }^{25}$ Letter from Surat to Amsterdam, Koloniaal Archief, Den Haag, 1839 p. 209. Quoted in: Sanjay Subrahmanyam and Muzaffar Alam, ed., The Mughal State 1526, 373.
} 
by the news that the Mogul is dead" ${ }^{26}$ and on April $7^{\text {th }}$, a resolution is passed by the Council at Fort William, Calcutta that:

"Considering the emperor's death and the scarcity there may be of provisions, and the want they may have at Madras, agree to order that 5,000 maunds of rice and 1,000 maunds of wheat be provided by Mr Arthur King [...] and to supply Fort St. George if they be in want of the same." 27

However, subsequent letters and reports mention no major disruption of communication or obstructions to trade of any kind and hence it may be suggested that Ashin Das Gupta was right in his assumption that the impact of the decline of Mughal administration after 1707 was most severely felt only in the Mughal heartland around Delhi and Agra.

Interestingly the problems of trade, mentioned by the Dutch factors, concur with the theory of Douglas North which mentions the absence of security and assurance as major factors that can potentially increase transaction costs and disincentivise economic activities causing a decline in wealth. ${ }^{28}$ It would not entirely be irrational to suggest that this destabilization of the Mughal heartland in western and northern India was responsible for the eastward shift of the main economic actors namely the European traders and the indigenous banking firms and agencies.

\section{Bankers and Rulers}

So far, we have focussed on the higher layers of the Mughal administrative system and seen that the existence, strength and competence of the person at the helm was crucial for the sustenance of the Pax Mughalica for which there is good evidence. However, historians such as Karen Leonard and P. J. Marshall have argued that the Mughal body politic was composed of more than just the elite actively engaged in administration such as the governors (subahdars) and princes.

Leonard argues that merchants and more importantly bankers were in fact not a segmental, but strategic elites in the Mughal political system who enjoyed consistent backing and supported the state during times of war and peace. Leonard in fact goes to the extent of

\footnotetext{
${ }^{26}$ Charles R. Wilson, The Early Annals of the English in Bengal: Bengal Public Consultations for the First Half of the Eighteenth Century, Eummarised, Extracted, and Edited with Introductions and Illustrative Addenda (London: Thacker, 1895), 280.

${ }^{27}$ Same as above.

${ }^{28}$ North, Institutions, Institutional Change and Economic Performance, 83-91.
} 
arguing, in the course of her 'Great Firm Theory of Mughal Decline,' that the loss of support from these banking firms like the Jagat Seth caused the capabilities of the centralised state to shrink rapidly and contributed to the growing power of the regional elites; paradigmatic of which for this essay, would be the increasingly independent Subah (province) of Bengal.

Sudhindra Nath Bhattacharya writes that Bengal was brought into the Mughal fold at the time of Emperor Akbar but the real power of the Mughals was felt there only after Jahangir's ascension. ${ }^{29}$ By the time of Aurangzeb, Bengal accounted for $50 \%$ of the Gross Domestic Product of the empire translating into about $12 \%$ of the world's GDP. Bengal also sent the largest tribute and share of revenue to the Mughal exchequer at the time of Aurangzeb making the province indispensable for the empire's economic welfare ${ }^{30}$.

\section{Bankers on the Move}

Any degree of understanding of subcontinental trade in the $18^{\text {th }}$ century is incomplete without the role of the banking and merchant firms that lubricated and facilitated the trade network. From the Dutch records cited above, it is clear that they were in fact crucial in the conduct of business as they (the 'shroffs') carried out the function of remittance of cash from one part of the country to another through the use of 'hundi'(s) or payment orders that could be transferred across the country. The ceasing of business activities by the shroffs is cited as a reason for major disruption in trade in the 1708-10 letters.

Interestingly, the main banking firms and families themselves appear to be on the move at this crucial juncture and Kumkum Chatterjee has outlined how the movement of the major banking firms shows a tendency to migrate towards the east into Bengal (Dacca or Murshidabad) and Bihar (Patna). The major firms in Patna in the $18^{\text {th }}$ century include the houses of Gopaldas-Manohardas, Ramchand-Gopalchand Shahu, Kishen Deo Tiwari, Premraj-Manikchand etc. but the most powerful and influential of these was undoubtedly the house of Jagat Seth ${ }^{31}$.

The firm was founded by Manek Chand who rendered critical financial assistance to Aurangzeb and received the title 'Jagat Seth' along with several privileges from the emperor.

\footnotetext{
${ }^{29}$ Sudhindra Nath Bhattacharya, 'State of Bengal Under Jahangir', in Sir Jadu-Nath Sarkar (ed.), The History of Bengal: Muslim Period 1200 - 1757 (New Delhi: Janaki Prakashan, 1977), 234.

${ }^{30}$ Karen Leonard, 'The 'Great Firm' Theory of the Decline of the Mughal Empire', in Muzaffar Alam and Sanjay Subrahmanyam (ed.), The Mughal State, 406.

${ }^{31}$ Kumkum Chatterjee, Merchants, Politics and Society in Early Modern India: Bihar: 1733 - 1820 (Leiden: Brill, 1996), 182.
} 
This firm not only had access to the Murshidabad mint, but also had a monopoly in handling the government's finances and was responsible for the remittance of the province's tribute to Delhi. ${ }^{32} \mathrm{He}$ also had direct access to the Emperors since Aurangzeb till the 1730s. The original base of operations of the firm was in Agra but at the turn of the century and as the Mughal heartland became increasingly unstable, their headquarters migrated eastward into Varanasi, Patna, Dacca and finally settled in Murshidabad after the governor of Bengal Murshid Quli Khan shifted the capital of the province there. ${ }^{33}$ Other firms such as that of Amir Chand (or Omichand) demonstrate a similar pattern-suggesting that this trend can be generalised to the majority of firms.

The instability of the Mughal heartland, partly originating from the continual raids of the Marathas and the failure of the government in protecting the bankers and merchants also caused a number of Gujarati firms to migrate into Maratha territory and become bankers to the Peshwa. ${ }^{34}$

This movement of bankers is in line with the North's assumptions regarding transaction costs as they are seen moving from institutionally unstable regions that would incur high transaction costs to regions of political stability. But the crucial point here is that great banking firms existed and flourished in the heyday of the Mughal empire in its political centre and were in fact crucial for the survival of the regime. As Karen Leonard maintains, the central function of the bankers with regard to the state was to provide cash for the payment of regular salaries in a situation when land-revenues were only available seasonally. ${ }^{35}$ In fact, Irfan Habib was surprised to discover that the largest share of the gold and silver bullion imported into India was actually bought by the shroffs and not by jewellers, as was expected. ${ }^{36}$ Leonard also cites instances when the abilities of the state were limited by refusal of assistance from the bankers. Irfan Habib discovered that an attempt by Aurangzeb to secure 500,000 rupees in interest-free loans in 1702 for troop payment during his Deccan campaign was turned down by the bankers ${ }^{37}$ which might suggest sufficient power and autonomy rested in their hands and that their rational self-interest was not overpowered by imperial decrees and demands as Jones appears to suggest.

\footnotetext{
${ }^{32}$ Kumkum Chatterjee, Merchants, Politics and Society in Early Modern India, 182.

${ }^{33}$ Karen Leonard, 'The 'Great Firm' Theory of the Decline of the Mughal Empire', 404.

${ }^{34}$ Muzaffar Alam and Sanjay Subrahmanyam (ed.), The Mughal State, 408-9.

${ }^{35}$ Karen Leonard, 'The 'Great Firm' Theory of the Decline of the Mughal Empire', in Muzaffar Alam and Sanjay Subrahmanyam (ed.), The Mughal State, 404.

${ }^{36}$ Karen Leonard, 'The 'Great Firm' Theory of the Decline of the Mughal Empire', 406.

${ }^{37}$ Irfan Habib, "Usury in Medieval India," Comparative Studies in Society and History Vol. 6, no. 4 (Jul., 1964): 408-9.
} 


\section{The Local Courts and the Post-Mughal Order}

In addition to despotic government, Eurocentric historians in the debate including Jones argue that the Mughal and even the post-Mughal political orders in India, were not conducive for trading activities as they did not protect trading rights and contracts which are, again factors that North claims hampers economic growth. In this section, we shall briefly look into instances of clear intervention on the part of the Indian administrations in the case of commercial disputes.

The English Factory Records contain a copy of an agreement between the "English and the Surat Authorities" dating from September 1624 which states that:

"it is agred that the English shall freely trade at their pleasure in the ports of Surat,

Cambaya, Baroch, Goga, Bengala, Scyndam and in other the cities of the Kings dominions ${ }^{\prime 38}$

This agreement from Emperor Jahangir allowed the English, and similar treaties with other Europeans, the Dutch, French, Danish etc. to trade in India throughout the Mughal empire. However, in 1628, the Council at Surat is informed that: "the Kings ferman is in divers places obeyed, and in some not regarded, in which places wee are forced to paie as they please" ${ }^{\text {39 }}$ which has driven historians to conclude that the Mughal empire's courts and law administration was but a show and ineffective. However, in addition to C. Bayly's work on the complexity of the Mughal system, we might cite repeated mentions and long periods of waiting that had to be endured by the European traders in order to secure the 'Kings ferman' which would certainly hint at their necessity.

Chatterjee cites specific cases of the intervention of the courts at Patna and Murshidabad in relation to the trade in saltpetre from Bihar in the early $18^{\text {th }}$ century ${ }^{40}$. Her work shows that the $\operatorname{durbar}(\mathrm{s})$ at Patna and Murshidabad actively participated in arbitrating an extremely tense competition between the various European powers as well as with the Indian counterparts - mainly the merchant-agents such as Amir Chand and Deep Chand.

\footnotetext{
38 'The Agreement Between the English and the Surat Authorities' dated September 7, 1624, published in: Foster, English Factories in India 1624 - 1629, 27.

${ }^{39}$ Robert Clitherow and John Goodwin at Nerrer to the President and Council at Surat, dated March 21, 1628, Foster, English Factories in India 1624 - 1629, 273.

${ }^{40}$ Kumkum Chatterjee, Merchants, Politics and Society in Early Modern India: Bihar: 1733 - 1820 (Leiden: Brill, 1996), 79-83.
} 
One particular instance of active involvement dates from 1744 when the Bihar administration sent 150 armed guards to surround the English factory upon receiving a complaint from Amir Chand and a shroff Hukum Chand that the chief of the English establishment - Humphrey Cole was planning to leave the city without settling his debts with these merchants. ${ }^{41}$ The siege was lifted only after their grievances were redressed and the durbar was paid a handsome sum of Rs. 1000 .

It would, at the same time, be wrong to assume that all intervention by the court only protected the interests of Indian businessmen against those of the Europeans. The English records from September 1734 show that the Company was apprehensive as a certain Meer Chand was buying large quantities of saltpetre and they were losing out in competition. An appeal to the Patna durbar resolved the issue as it sanctioned an English monopoly on collecting saltpetre for the rest of the season. ${ }^{42}$ Unfortunately, as Chatterjee notes, the very next year, the English lost out in their own game as the French and Dutch applied the same tactic to gain a monopoly on the sought commodity. ${ }^{43}$

In sum, it is difficult to imagine a completely lawless state wielding this degree of political control sufficient to influence the market structure for commodities (perfect competition, monopoly, monopsony etc.) and as the two reports from the 1620 s show, Mughal central control, even in its heyday was never as geographically extensive as Jones or even Eisenstein would care to admit — rather it was always about finding the best way to incorporate and subordinate existing power structures including bankers, and regional elites which were influential and created their own microcosm of peace and security as C. Bayly rightly gauged.

\section{Conclusion: The Pax Mughalica?}

If we return to the question posed in the title of this essay, whether the Mughal empire was the classic oriental despotic state that Jones criticises for causing India's economic decline after the eighteenth century, it is essentially about asking, whether the Mughal political order was a blessing or a nuisance. Relying on European accounts is problematic due to several reasons that Sanjay Subrahmanyam has outlined in detail, but in the absence of accessible and available Indian sources, one may conclude that the Indian state system that

\footnotetext{
${ }^{41}$ Bengal Public Consultations, Range 1, vol. 16, consultation January 20, 1744.

${ }^{42}$ Bengal Public Consultations, Range 1, vol. 10, consultation September 27, 1734.

${ }^{43}$ Chatterjee, Merchants, Politics and Society in Early Modern India, 85.
} 
appears to have existed was not markedly different from that of medieval or early modern Europe.

Both the state systems saw a reliance on a banking-trading class for financial activities especially in war time as Aurangzeb seems to have employed for his Deccan campaigns $^{44}$ and both saw patterns of migration of capital from regions of political turmoil to those of stability as seen after the death of Aurangzeb. And although wars of succession appear to be an endemic problem, their widescale disruptive feature is probably an inventive assumption of Jones'.

The Eurocentric argument about laws and political regimes inconducive to commerce seems untenable as there appears to be a strong alliance and involvement of regional courts in the commercial activities of those regions after the weakening of the empire; but given the reports of invalidity of Mughal decrees even in the 1620s across the empire, the Mughal centre hardly appears to have superseded the provincial power-base even at its peak.

Moreover, the inclusion of bankers and money-changers in close court circles as strategic elites and giving them a very considerable degree of autonomy, as has been described already, attacks the arguments by Jones about a parasitic elite class very critically.

And finally, the economic rise of Bengal, although can be justified through the model of a competitive state structure as Eric Jones suggests was the case for Europe, it is important to realise that Bengal became a viable centre for trade and commerce due to the survival of the Pax Mughalica in small pockets in states such as Bengal which continued to function and express themselves within the Mughal ecumene and culture of power. Furthermore, Bengal's economic growth at the expense of the Mughal heartland and the movement of the bankers is a strong testament to the agility of the South Asian commercial systems - and a direct refutation of Jones' picture of India.

In conclusion, it may be said that there is necessary evidence to suggest that the Mughal administrative structure including its market control and provisions of security played a crucial part in bringing about the explosion of trading activities in the late seventeenth century and its weakening in the Mughal heartland only resulted in a migration of economic institutions to regions where this system survived such as Bengal and the

\footnotetext{
${ }^{44}$ See: Michele Fratianni, and Franco Spinneli, "Italian City-states and Financial Evolution." European Review of Economic History 10, no. 3 (2006): 257-78. http://www.jstor.org/stable/41378446 and Mauricio Drelichman, and Hans-Joachim Voth, "LENDING TO THE BORROWER FROM HELL: DEBT AND DEFAULT IN THE AGE OF PHILIP II," The Economic Journal 121, no. 557 (2011): 1205-227. http://www.jstor.org/stable/41301355.
} 
Maratha territories. It is therefore in contradiction to Jones' analyses claiming that the Mughal system was a disincentive to commerce and that although the emergence of smaller successor states seem to have been a positive development, one must bear in mind that in reality they always existed, if only in a dwarfed form-from which they sprung into prominence with the increasing chaos in the heartland - and their emboldening was also due to the same political institutions that the Mughal system created in the first place.

These contradictions appear to be what keeps the Great Divergence debate alive. The system through which power was exercised in India, for example the exact method through which taxes were collected remain to be known along with the real perception of the people of the changing political scenario. However, it appears unlikely that knowledge into these areas would solve the apparent contradictions in the political scene of $18^{\text {th }}$ century India allowing for a broad and generalized answer to why Europe grew rich and India did not. In the end, perhaps we have to agree with Christopher Bayly:

"Indian society is so complex, that any unqualified exposition of historical trend must be superficial, and any deeper one will become enmeshed in paradox." 45

\footnotetext{
${ }^{45}$ C.A. Bayly, 'The Rise of the Corporations', in Rulers, Townsmen and Bazaars: North Indian Society in the Age of British Expansion, 1770 - 1870 (Cambridge: Cambridge University Press, 1983), 163.
} 


\section{References}

\section{Literature and Secondary Sources}

Acemoglu, Daron, and James A. Robinson. Why Nations Fail: The Origins of Power, Prosperity and Poverty. New York: Crown, 2012.

Alam, Muzaffar, and Sanjay Subrahmanyam. The Mughal State, 1526-1750. Oxford in Indian Readings. Themes in Indian History. Delhi: Oxford University Press, 1998.

Barnett, Richard B. Rethinking Early Modern India. New Delhi: Manohar, 2002.

Chatterjee, Kumkum. Merchants, Politics and Society in Early Modern India: Bihar: 1733 1820. Leiden: Brill, 1996.

Cohn, Bernard S. "Political Systems in Eighteenth Century India: The Benaras Region", Journal of the American Oriental Society vol. 82 no. 3(1962): 312-330.

Das Gupta, Ashin. India and the Indian Ocean World: Trade and Politics. New Delhi: Oxford University Press, 2004.

Drelichman, Mauricio, and Hans-Joachim Voth. "Lending to The Borrower from Hell: Debt and Default in the Age of Philip II." The Economic Journal 121, no. 557 (2011): 1205-227. http://www.jstor.org/stable/41301355.

Fratianni, Michele, and Franco Spinelli. "Italian City-states and Financial Evolution." European Review of Economic History 10, no. 3 (2006): 257-78. http://www.jstor.org/stable/ $\underline{41378446 .}$.

Habib, Irfan. "Usury in Medieval India." Comparative Studies in Society and History 6, no. 4 (1964): 393-419. http://www.jstor.org/stable/177929. Accessed April 09, 2019.

Hasan, S. Nurul. "The Theory of The Nur Jahan 'Junta'-A Critical Examination," Proceedings of the Indian History Congress 21 (1958): 324-35.

http://www.jstor.org/stable/44145220.

Jones, Eric. The European Miracle: Environments, Economies and Geopolitics in the History of Europe and Asia. Cambridge: Cambridge University Press, 2003.

Karen. Leonard. "The 'Great Firm' Theory of the Decline of the Mughal Empire." Comparative Studies in Society and History 21, no. 2 (1979): 151-67.

http://www.jstor.org/stable/178414.

Marshall, P. (ed.) The Eighteenth Century in Indian History: Evolution or Revolution. New York: Oxford University Press, 2003.

North, Douglas. Institutions, Institutional Change and Economic Performance. Cambridge: Cambridge University Press, 1990.

Parthasarathi, Prasannan. Why Europe Grew Rich and Asia Did Not: Global Economic Divergence 1600 - 1850. Cambridge: Cambridge University Press. 
Roy, Tirthankar. Traditional Industry in the Economy of Colonial India. Cambridge Studies in Indian History and Society, 5. New York: Cambridge University Press, 1999.

Said, Edward. Orientalism. New York: Vintage Books, 1978.

Sarkar, Sir Janu-Nath (ed.). The History of Bengal: Muslim Period 1200 - 1757. New Delhi: Janaki Prakashan, 1977.

Subrahmanyam, Sanjay, ed. Merchants, Markets and the State in Early Modern India. Delhi: Oxford University Press, 1990.

Subrahmanyam, Sanjay. Explorations in Connected History: Mughals and Franks. New Delhi: Oxford University Press, 2011.

V. Ball and W. Cooke, trans. and ed., Travels in India by Jean-Baptiste Tavernier, Baron of Aubonne, 2 Volumes, reprint New Delhi, 1977, 334.

\section{Primary Sources}

Bengal Public Consultations, Range 1, vol. 16, consultation January 20, 1744. Published in: Charles R. Wilson, The Early Annals of the English in Bengal: Bengal Public Consultations for the First Half of the Eighteenth Century, Summarised, Extracted, and Edited with Introductions and Illustrative Addenda (London: Thacker, 1895).

Bengal Public Consultations, Range 1, vol. 10, consultation September 27, 1734. Published in: Charles R. Wilson, The Early Annals of the English in Bengal: Bengal Public Consultations for the First Half of the Eighteenth Century, Summarised, Extracted, and Edited with Introductions and Illustrative Addenda (London: Thacker, 1895).

'The Agreement Between the English and the Surat Authorities' dated September 7, 1624. Published in: William Foster (ed.), The English Factories in India 1624 - 1629: A Calendar of Documents in the India Office Etc. (Oxford: Clarendon Press, 1909).

Robert Clitherow and John Goodwin at Nerrer to the President and Council at Surat, dated March 21, 1628. Published in: William Foster (ed.), The English Factories in India 1624 1629: A Calendar of Documents in the India Office Etc. (Oxford: Clarendon Press, 1909).

Report by Gregory Clement, John Bangham, Robert Clitherow, Ralph Cartwright and John Goodwin at Agra to the President and Council at Surat, dated February 17, 1628. Published in: William Foster (ed.), The English Factories in India 1624 - 1629: A Calendar of Documents in the India Office Etc. (Oxford: Clarendon Press, 1909).

Report by President Kerridge, Richard Wylde, John Skibbow, Joseph Hopkins, William Martin and George Page at Surat to The Company, dated January 4, 1628. Published in: William Foster (ed.), The English Factories in India 1624 - 1629: A Calendar of Documents in the India Office Etc. (Oxford: Clarendon Press, 1909). 